\title{
HUBUNGAN DERAJAT STUNTING, ASUPAN ZAT GIZI DAN SOSIAL EKONOMI RUMAH TANGGA DENGAN PERKEMBANGAN MOTORIK ANAK USIA 24 - 36 BULAN DI WILAYAH KERJA PUSKESMAS BUGANGAN SEMARANG
}

\author{
Novita Milda Susanty, Ani Margawati*) \\ Program Studi Ilmu Gizi Fakultas Kedokteran Universitas Diponegoro \\ Jl.Dr.Sutomo No.14, Semarang, Telp (024) 8453708, Email : gizifk@undip.ac.id
}

\begin{abstract}
Background: The prevalence of stunting status in Indonesia is still high. It should be a serious concern because stunting is an indicator of chronic malnutrition that related with motoric development and affect indirectly human resources quality. Beside stunting, motoric development is also affected by another factor are nutrients intake and socioeconomic of families.

Objective: The aim of this study were to determine relationship between degree of stunting, nutrients intake and socioeconomic of families with motoric development of children 24-36 months of age.

Methods: This was cross sectional study on 43 children whom were chosen by consecutive sampling. Degree of stunting were expressed by height for age z-score (HAZ) according to the WHO classification. Nutrients intake (energy, protein, iron and zinc) were collected through semi quantitative food frequency (FFQ) questionnaire. Socioeconomic of families (education of mother, mother's occupation, families income) were collected through interview. Motoric developments were measured with Denver II test. Data analysis used Fisher Exact test.

Result: More than half of subject (53,5\%) were in moderate degree of stunting. Intake of energy (23,3\%), protein (14\%), iron (69,8\%), zinc $(72,1 \%)$ were under of individual recommended daily intake. Education of mother $60,5 \%$ were high category. 57,4\% mother were'nt working and 46,5\% families had low income. Gross and fine motoric development each 16,3\% and $14 \%$ were suspect. There were significant relationship between intake of energy with fine motoric development $(p=0,040)$ and gross motoric development $(p=0,020)$. There were significant relationship between intake of protein with fine motoric development $(p=0,045)$ and gross motoric development $(p=0,027)$. There were not correlation between degree of stunting, iron and zinc intake, education of mother, occupation of mother, and families income with gross and fine motoric development ( $p>0,05)$.

Kesimpulan: There were significant relationship between intake of energy and protein with fine and gross motoric development.
\end{abstract}

Keywords: degree of stunting; nutrient intake; socioeconomics of families; motoric development

\section{ABSTRAK}

Latar Belakang : Masih tingginya prevalensi stunting di Indonesia menjadi hal yang harus diperhatikan. Hal ini karena stunting merupakan indikator malnutrisi kronik yang berkaitan dengan perkembangan motorik dan secara tidak langsung mempengaruhi kualitas sumber daya manusia. Selain stunting, perkembangan motorik dipengaruhi faktor lain, beberapa diantaranya asupan zat gizi dan sosial ekonomi rumah tangga.

Tujuan: Penelitian ini bertujuan menganalisis hubungan derajat stunting, asupan zat gizi dan sosial ekonomi rumah tangga dengan perkembangan motorik anak balita usia 24-36 bulan.

Metode: Desain penelitian adalah cross-sectional dengan jumlah sampel 43 anak, diambil dengan metode consecutive sampling. Penilaian derajat stunting dinyatakan dengan z-score tinggi badan menurut umur (TB/U) dan diklasifikasikan berdasarkan WHO. Asupan zat gizi (energi, protein, besi, seng) diukur melalui metode formulir semi quantitative food frequency (FFQ). Sosial ekonomi keluarga (pendidikan ibu, pekerjaan ibu, dan pendapatan perkapita rumah tangga) diperoleh melalui wawancara. Perkembangan motorik diukur dengan tes Denver II. Analisis data dengan uji Fisher Exact.

Hasil: Sebanyak 53,5\% subjek termasuk moderate stunting. Asupan energi (23,3\%), protein (14\%), besi (69.8\%), dan seng $(72,1 \%)$ kurang dari AKG individu. Pendidikan ibu 60,5\% relatif tinggi. Sebanyak $67,4 \%$ ibu tidak bekerja, dan 53,5\% pendapatan per kapita rumah tangga tergolong cukup. Perkembangan motorik kasar dan halus masing-masing 16,3\% dan 14\% dicurigai ada keterlambatan. Hasil uji korelasi menunjukan ada hubungan asupan energi dengan perkembangan motorik halus $(p=0,040)$ dan motorik kasar $(p=0,020)$. Ada hubungan asupan protein dengan perkembangan motorik halus $(p=0,045)$ dan motorik kasar $(p=0,027)$. Tidak ada hubungan antara derajat stunting, asupan besi, asupan seng, pendidikan ibu, pekerjaan ibu dan pendapatan per kapita rumah tangga dengan perkembangan motorik halus dan kasar ( $p>0,05)$.

Kesimpulan: Asupan energi dan protein berhubungan dengan perkembangan motorik halus dan kasar anak balita.

\footnotetext{
${ }^{*}$ Penulis Penanggungjawab
} 
Kata Kunci : Derajat stunting; asupan zat gizi; sosial ekonomi rumah tangga; perkembangan motorik

\section{PENDAHULUAN}

Masalah gizi merupakan masalah utama kesehatan masyarakat di sebagian besar negara berkembang, terutama pada balita, anak-anak, dan wanita usia produktif. Indonesia merupakan negara berkembang yang masih menghadapi masalah gizi seperti kekurangan energi protein, gangguan akibat kekurangan yodium, anemia gizi besi, dan kekurangan vitamin A. Beberapa masalah gizi diatas sering dialami oleh balita dan sampai dengan sekarang belum dapat terselesaikan. ${ }^{1}$

Berdasarkan hasil Riset Kesehatan Dasar (Riskesdas) tahun 2010 diketahui prevalensi nasional balita dengan status gizi buruk $4,9 \%$, gizi kurang $13 \%$, dan stunting $35,6 \%$. Dalam perjalanannya, Indonesia dapat dikatakan berhasil karena sudah dapat menurunkan prevalensi gizi buruk dan gizi kurang dari $31 \%$ pada tahun 1989 menjadi $17.9 \%$ pada tahun 2010. Akan tetapi yang menjadi masalah serius sekarang adalah masih tingginya prevalensi stunting. ${ }^{2}$ Prevalensi balita stunting tahun 2010 di Jawa tengah yaitu 33,9\%. Angka kejadian stunting di kota Semarang tahun 2011 sebesar 20,66\%, sedangkan di kecamatan Semarang Timur mencapai 40,16\%. ${ }^{3}$

Masa balita merupakan periode kritis perkembangan anak terutama pada usia tiga tahun pertama. Pada usia tersebut, rentan terjadi malnutrisi. ${ }^{4} \quad$ Stunting merupakan keaadaan malnutrisi kronik yang berkaitan dengan perkembangan otak anak. Hal ini disebabkan oleh adanya keterlambatan kematangan sel-sel saraf terutama di bagian cerebellum yang merupakan pusat koordinasi gerak motorik., ${ }^{5,6}$ Beberapa penelitian menunjukkan bahwa stunting berhubungan dengan perkembangan motorik anak. ${ }^{7,8}$ Perkembangan motorik merupakan aspek perkembangan yang penting karena berkaitan dengan aspek perkembangan yang lain, terutama perkembangan kognitif. Perkembangan kognitif inilah yang secara tidak langsung akan mempengaruhi kualitas Sumber Daya Manusia $(\mathrm{SDM}){ }^{9}$

Asupan zat gizi merupakan kebutuhan anak yang berperan dalam proses tumbuh kembang terutama tumbuh kembang otak dan dibutuhkan di masa-masa rawan yaitu trimester ketiga kehamilan sampai usia tiga tahun. Asupan zat gizi yang penting untuk fungsi motorik meliputi enegi, protein, besi, dan seng. Energi dan protein berperan dalam proses proliferasi, difersensiasi sel, dan synaptogenesis. Besi berperan dalam sintesis monoamine, metabolisme energi di neuron dan sel glia, serta mielinisasi. Seng berperan dalam sintesis DNA dan pelepasan neurotransmitter. ${ }^{4}$ Hasil penelitian di Yogyakarta menunjukkan bahwa asupan energi, protein, zat besi, dan seng dalam makanan pendamping ASI mempunyai hubungan yang bermakna dengan pekembangan bayi usia 611 bulan. $^{10}$

Perkembangan motorik anak tidak hanya dipengaruhi oleh derajat stunting dan asupan zat gizi, tetapi juga faktor sosial ekonomi rumah tangga. Peranan dari sisi sosial rumah tangga terutama ibu dalam mengasuh anak sangat penting dalam proses tumbuh kembang anak. Pendidikan ibu dan pekerjaan ibu diketahui berhubungan dengan perkembangan motorik anak. Pendidikan yang rendah menyebabkan terbatasnya pengetahuan ibu mengenai tumbuh kembang anak. Hal ini menyebabkan rendahnya kualitas pola asuh dan stimulan yang diberikan. Status pekerjaan ibu akan sangat mempengaruhi interaksi ibu dengan anak. Interaksi ibu dengan anak inilah yang jadi bagian penting dalam proses perkembangan anak. ${ }^{11}$ Pendapatan rumah tangga merupakan faktor ekonomi yang juga secara tidak langsung mempengaruhi perkembangan anak. Hal ini berkaitan dengan kemampuan orang tua dalam menyediakan fasilitas yang mendukung pertumbuhan dan perkembangan anak. ${ }^{12}$

Puskesmas Bugangan merupakan salah satu puskesmas yang ada di kecamatan Semarang Timur. Berdasarkan data dari puskesmas tersebut pada tahun 2011 diketahui bahwa 27,4\% dari 566 balita memiliki status gizi stunting. ${ }^{13}$ Berdasarkan uraian diatas, maka perlu dilakukan penelitian mengenai hubungan derajat stunting, asupan zat gizi, dan sosial ekonomi rumah tangga dengan perkembangan motorik balita usia $24-36$ bulan di wilayah kerja Puskesmas Bugangan. Hasil penelitian ini diharapkan dapat memberikan informasi mengenai pentingnya status gizi dan asupan gizi balita serta peran sosial ekonomi keluarga sebagai upaya mencapai perkembangan motorik yang optimal dan sumber daya manusia yang berkualitas.

\section{METODE}

Penelitian ini termasuk dalam lingkup penelitian gizi masyarakat dan merupakan penelitian obeservasional dengan pendekatan cross sectional. Populasi target dalam penelitian ini adalah anak balita usia 24 - 36 bulan, sedangkan 
populasi terjangkau adalah anak balita usia $24-36$ bulan di wilayah kerja Puskesmas Bugangan Kecamatan Semarang Timur. Jumlah subjek yang diperlukan untuk penelitian ini adalah 43 anak. Subjek ditentukan dengan dengan metode consecutive sampling, dengan kriteria yaitu orang tua anak bersedia menjadi responden, balita berusia 24-36 bulan, memiliki status gizi menurut tinggi badan menurut umur dengan $z$-score $<-1$ $\mathrm{SD}$, dan anak tidak dalam kondisi sakit saat pengukuran perkembangan motorik.

Variabel bebas terdiri dari derajat stunting, asupan zat gizi (energi, protein, besi, seng) dan sosial ekonomi rumah tangga (pendidikan dan pekerjaan ibu, serta pendapatan per kapita rumah tangga). Variabel terikat yaitu pekembangan motorik halus dan kasar.

Derajat stunting didefinisikan sebagai ukuran status gizi berdasarkan indeks tinggi badan (TB) menurut umur (U) baku rujukan WHO dalam nilai $z$-score, dan dikategorikan menjadi mild stunting (-2 $\mathrm{SD} \leq z$-score $<-1 \mathrm{SD})$, moderate stunting $(-3 \mathrm{SD} \leq z$-score $<-2 \mathrm{SD})$, severe stunting (z-score <-3SD). ${ }^{14}$ Data asupan zat gizi didapat dengan menggunakan kuisioner food frequency semi quantitative, kemudian diolah dengan menggunakan program nutrisurvei untuk mendapatkan data asupan zat gizi energi, protein, besi, dan seng. Selanjutnya asupan zat gizi tersebut dibandingkan dengan kebutuhan masing-masing individu dan dikategorikan menjadi kurang dan baik. Tingkat asupan zat gizi (energi, protein, besi, dan seng) dikategorikan kurang jika $<100 \%$ kebutuhan perindividu, tergolong baik jika $\geq 100 \%$ kebutuhan perindividu. ${ }^{15}$ Pendidikan ibu didefinisikan sebagai pendidikan formal terakhir yang ditamatkan ibu dan dikategorikan menjadi rendah ( $\leq$ SMP) dan tinggi ( $\geq$ SMA) ${ }^{16}$ Pekerjaan ibu adalah pekerjaan yang rutin dilakukan oleh ibu. Dikatakan bekerja bila ibu setiap hari bekerja tetap di luar rumah dan tidak bekerja jika setiap hari hanya tinggal di rumah sebagai ibu rumah tangga dan hanya meninggalkan rumah sesaat. ${ }^{7}$ Pendapatan per kapita rumah tangga adalah seluruh pendapatan anggota keluarga per bulan yang dapat digunakan untuk pembelanjaan pangan dan non pangan dibagi jumlah anggota keluarga dan dinilai dalam satuan rupiah kemudian dikategorikan kurang ( $\leq \mathrm{Rp} 234.799,00)$ dan cukup $(>\mathrm{Rp}$ 234.799,00). ${ }^{17}$

Perkembangan motorik halus didefinisikan sebagai kemampuan anak untuk mengamati sesuatu, melakukan gerakan yang melibatkan bagian-bagian tubuh tertentu dan dilakukan otototot kecil, tetapi memerlukan koordinasi yang cermat. Perkembangan motorik kasar adalah kemampuan anak melakukan pergerakan dan sikap tubuh yang melibatkan otot-otot besar. ${ }^{18}$ Pengukuran perkembangan motorik halus dan kasar menggunakan tes Denver II yang disesuaikan dengan umur balita kemudian hasil tes diskoring dengan kategori lulus, gagal, dan menolak. Hasil skoring kemudian diinterpretasi dengan kategori lebih bila anak lulus pada aitem tes yang terletak di kanan garis umur; normal bila anak gagal atau menolak melakukan suatu aitem tes disebelah kanan garis umur atau anak dapat lulus, gagal, atau menolak tes dimana garis umur terletak diantara $25 \%$ dan $75 \%$; peringatan bila anak gagal atau menolak melakukan aitem tes dimana garis umur terletak pada atau antara $75 \%$ sampai 90\%; dan keterlambatan bila anak menolak atau gagal melakukan aitem tes yang tereletak di sebalah kiri garis umur.. Hasil interpretasi kemudian dibuat kesimpulan dengan klasifikasi normal bila tidak ada keterlambatan dan atau paling banyak satu peringatan dan diklasifikasikan suspek (dicurigai ada keterlambatan) bila ada $\geq 2$ peringatan dan atau $\geq 1$ keterlambatan. ${ }^{19}$

Data yang dikumpulkan antara lain karakteristik anak balita, sosial ekonomi rumah tangga (pendidikan dan pekerjaan ibu, serta pendapatan per kapita rumah tangga), derajat stunting, asupan zat gizi (energi, protein, besi dan seng), dan data pengukuran perkembangan motorik halus dan kasar. Analisis univariat digunakan untuk mendiskripsikan data-data yang sudah dikumpulkan. Analisis bivariat dengan menggunakan uji Chi-Square. Namun karena semua analisis tidak memenuhi syarat uji ChiSquare yaitu tidak boleh ada sel yang nilai expected-nya kurang dari lima, maka uji yang dipakai adalah uji Fisher Exact.

\section{HASIL PENELITIAN \\ Karakteristik Subjek}

Subjek penelitian berjumlah 43 anak dengan rentang usia 24-36 bulan dan rerata $29 \pm 4,2$ bulan. Berdasarkan jenis kelamin $15(34,9 \%)$ subyek adalah laki-laki dan $28(65,1 \%)$ adalah perempuan.

\section{Sosial Ekonomi Rumah Tangga Subjek}


Tabel 1. Distribusi Frekuensi Sosial Ekonomi Rumah Tangga Subjek

\begin{tabular}{|c|c|c|}
\hline Sosial Ekonomi Rumah Tangga & Frekuensi (n) & Persentase $(\%)$ \\
\hline \multicolumn{3}{|l|}{ Pendidikan Ibu } \\
\hline - $\quad$ Rendah $(\leq \mathrm{SMP})$ & 17 & 39,5 \\
\hline - $\quad$ Tinggi (> SMA) & 26 & 60,5 \\
\hline \multicolumn{3}{|l|}{ Pekerjaan Ibu } \\
\hline - Bekerja & 14 & 32.6 \\
\hline - $\quad$ Tidak bekerja & 29 & 67.4 \\
\hline $\begin{array}{l}\text { Pendapatan per kapita rumah } \\
\text { tangga }\end{array}$ & 20 & 46,5 \\
\hline $\begin{array}{ll}- & \text { Kurang } \\
- & \text { Cukup }\end{array}$ & 23 & 53,5 \\
\hline
\end{tabular}

Tabel 3 menunjukkan bahwa pendidikan ibu sebagian besar termasuk kategori tinggi, sedangkan dalam hal pekerjaan sebagian besar ibu tidak bekerja. Pendapatan per kapita rumah tangga berkisar antara Rp 166.700 - Rp 931.476 dengan

rerata $\operatorname{Rp} 332.718 \pm 159.235,5$ dan $53,5 \%$ tergolong cukup.

\section{Derajat Stunting Subjek}

Tabel 2. Distribusi Frekuensi Derajat Stunting

\begin{tabular}{lcc}
\hline \multicolumn{1}{c}{ Derajat Stunting } & Frekuensi (n) & Persentase (\%) \\
\hline Mild Stunting & 15 & 34,9 \\
Moderate stunting & 23 & 53,5 \\
Severe stunting & 5 & 11,6 \\
\hline
\end{tabular}

Tabel 2 menunjukkan bahwa sebagian besar sampai dengan -1,18 SD dengan rerata -2,2 $\pm 0,69$ $(53,5 \%)$ termasuk kategori moderate stunting. SD. Nilai z-score TB/U berkisar antara $-4,03$ SD Asupan Zat Gizi

Tabel 3. Distribusi Tingkat Asupan Energi, Protein, Besi, dan Seng

\begin{tabular}{lcc}
\hline Asupan Zat Gizi & Frekuensi (n) & Persentase (\%) \\
\hline Energi & & \\
- Kurang & 10 & 23,3 \\
- Baik & 33 & 76,7 \\
Protein & 6 & 14 \\
$-\quad$ Kurang & 37 & 86 \\
- Baik & & \\
Besi & 30 & 69.8 \\
- Kurang & 13 & 30.2 \\
- Baik & & \\
Seng & 31 & 72,1 \\
- Kurang & 12 & 27,9 \\
- Baik & & \\
\hline
\end{tabular}

Dari tabel 3 tersebut dapat diketahui bahwa asupan energi dan protein $76,7 \%$ dan $86 \%$ tergolong baik. Asupan energi berkisar antara 705-1519 kkal dengan rerata 1056,7 $\pm 179,99 \mathrm{kkal}$. Asupan protein berkisar antara 18,2-46,1 g dengan rerata
32,9 $\pm 7,16$. Asupan besi dan seng subjek $69,8 \%$ dan $72,1 \%$ tergolong kurang. Asupan besi subjek berkisar antara 2,70-14,30 $\mathrm{mg}$ dengan rerata $6,7 \pm 3,15 \mathrm{mg}$. Asupan seng subjek berkisar antara $1,80-11,50 \mathrm{mg}$ dengan rerata $5,8 \pm 2,85 \mathrm{mg}$. 


\section{Perkembangan Motorik}

Tabel 4. Distribusi Frekuensi Perkembangan Motorik Halus dan Kasar

\begin{tabular}{lcc}
\hline Perkembangan Motorik & Frekuensi (n) & Persentase (\%) \\
\hline Motorik Halus & 7 & 16,3 \\
- Suspek & 36 & 83,7 \\
- Normal & & \\
Motorik Kasar & 6 & 14,0 \\
- Suspek & 37 & 86,0 \\
- Normal & & \\
\hline
\end{tabular}

Tabel 4 menunjukkan bahwa perkembangan motorik halus dan kasar sebagian besar subjek normal yaitu masing-masing dengan persentase $83,7 \%$ dan $86 \%$, sedangkan sebagian kecil dicurigai ada keterlambatan (suspek) yaitu 16,3\% dan $14 \%$.

Hubungan Derajat Stunting, Asupan Zat Gizi dan Sosial Ekonomi Rumah Tangga dengan Perkembangan Motorik

Tabel 5. Hubungan Derajat Stunting, Asupan Zat Gizi dan Sosial Ekonomi Rumah Tangga dengan Perkembangan Motorik Halus

\begin{tabular}{|c|c|c|c|c|c|}
\hline & \multicolumn{2}{|c|}{$\begin{array}{c}\text { Perkembangan } \\
\text { Suspek }\end{array}$} & \multicolumn{2}{|c|}{$\frac{\text { Motorik Halus }}{\text { Normal }}$} & \multirow[t]{2}{*}{$p$} \\
\hline & $\mathbf{n}$ & $\%$ & $\mathbf{n}$ & $\%$ & \\
\hline \multicolumn{6}{|l|}{ Derajat Stunting } \\
\hline Severe+ Moderate Stunting & 6 & 21,4 & 22 & 78,6 & 0,391 \\
\hline Mild Stunting & 1 & 6,7 & 14 & 93,3 & \\
\hline \multicolumn{6}{|l|}{ Asupan Energi } \\
\hline Kurang & 4 & 40 & 6 & 60 & $0,040^{*}$ \\
\hline Baik & 3 & 9,1 & 30 & 90,9 & \\
\hline \multicolumn{6}{|l|}{ Asupan Protein } \\
\hline Kurang & 3 & 50 & 3 & 50 & $0,045^{*}$ \\
\hline Baik & 4 & 10,8 & 33 & 89,2 & \\
\hline \multicolumn{6}{|l|}{ Asupan Besi } \\
\hline Kurang & 6 & 20 & 24 & 80 & 0,412 \\
\hline Baik & 1 & 7,7 & 12 & 92,3 & \\
\hline \multicolumn{6}{|l|}{ Asupan Seng } \\
\hline Kurang & 6 & 19,4 & 25 & 80,6 & 0,652 \\
\hline Baik & 1 & 8,3 & 11 & 91,7 & \\
\hline \multicolumn{6}{|l|}{ Pendidikan Ibu } \\
\hline Rendah & 4 & 23.5 & 13 & 76,5 & 0,407 \\
\hline Tinggi & 3 & 11,5 & 23 & 88,5 & \\
\hline \multicolumn{6}{|l|}{ Pekeriaan Ibu } \\
\hline Bekerja & 3 & 21,4 & 11 & 78,6 & 0,665 \\
\hline Tidak bekerja & 4 & 13,8 & 25 & 86,2 & \\
\hline \multicolumn{5}{|l|}{ Pendapatan per kapita rumah } & 0.22 \\
\hline Kurang & 2 & 8,7 & 21 & 91,3 & \\
\hline Cukup & & & & & \\
\hline
\end{tabular}

Berdasarkan tabel 5 dan 6 diketahui bahwa terdapat dua variabel yang secara statistika mempunyai hubungan yang bermakna dengan perkembangan motorik halus dan kasar anak balita yaitu asupan energi dan protein. 
Tabel 6. Hubungan Derajat Stunting, Asupan Zat Gizi dan Sosial Ekonomi Rumah Tangga dengan Perkembangan Motorik Kasar

\begin{tabular}{|c|c|c|c|c|c|}
\hline & \multicolumn{4}{|c|}{ Perkembangan Motorik Kasar } & \multirow[t]{3}{*}{$p$} \\
\hline & \multicolumn{2}{|c|}{ Suspek } & \multicolumn{2}{|c|}{ Normal } & \\
\hline & $\mathbf{n}$ & $\%$ & $\mathbf{n}$ & $\%$ & \\
\hline \multicolumn{6}{|l|}{ Derajat Stunting } \\
\hline Severe+ Moderate Stunting & 5 & 17,9 & 23 & 82,1 & 0,403 \\
\hline Mild Stunting & 1 & 6,7 & 14 & 93,3 & \\
\hline \multicolumn{6}{|l|}{ Asupan Energi } \\
\hline Kurang & 4 & 40 & 6 & 60 & $0,020^{\circ}$ \\
\hline Baik & 2 & 6 & 31 & 94 & \\
\hline \multicolumn{6}{|l|}{ Asupan Protein } \\
\hline Kurang & 3 & 50 & 3 & 50 & $0,027^{\circ}$ \\
\hline Baik & 3 & 8,1 & 34 & 91,9 & \\
\hline \multicolumn{6}{|l|}{ Asupan Besi } \\
\hline Kurang & 5 & 16,7 & 25 & 83,3 & 0,649 \\
\hline Baik & 1 & 7,7 & 12 & 92,3 & \\
\hline \multicolumn{6}{|l|}{ Asupan Seng } \\
\hline Kurang & 5 & 16,1 & 26 & 83,9 & 0,659 \\
\hline Baik & 1 & 8,3 & 11 & 91,7 & \\
\hline \multicolumn{6}{|l|}{ Pendidikan Ibu } \\
\hline Rendah & 3 & 17,6 & 14 & 82,4 & 0,666 \\
\hline Tinggi & 3 & 11,5 & 23 & 88,5 & \\
\hline \multicolumn{6}{|l|}{ Pekerjaan Ibu } \\
\hline Bekerja & 2 & 14,3 & 12 & 85,7 & 1,000 \\
\hline Tidak bekerja & 4 & 13,8 & 25 & 86,2 & \\
\hline \multicolumn{6}{|l|}{ Pendapatan per kapita rumah } \\
\hline Kurang & 3 & 13 & 20 & 87 & \\
\hline Cukup & & & & & \\
\hline
\end{tabular}

\section{PEMBAHASAN}

\section{Hubungan Derajat Stunting dengan Perkembangan Motorik}

Stunting merupakan indikator malnutrisi kronik yang menggambarkan riwayat kurang gizi dalam jangka waktu lama. ${ }^{20}$ Malnutrisi pada usia tiga tahun pertama diketahui berkaitan dengan perkembangan otak. ${ }^{4}$ Perkembangan otak anak yang malnutrisi mengalami perubahan struktur dan fungsi berupa penurunan jumlah mielin, dendrit kortikal dalam medulla spinalis, peningkatan mitokondria dalam sel-sel neuron dan saraf, dan reduksi sinapsis neurotransmitter yang berkaitan dengan mekanisme gerak motorik. ${ }^{6}$ Cerebellum adalah bagian otak yang merupakan pusat koordinasi gerak motorik dan paling rentan terkena dampak dari malnutrisi. ${ }^{5}$

Berdasarkan uraian diatas diketahui bahwa secara teoritis stunting mempunyai hubungan dengan perkembangan motorik anak balita. Akan tetapi pada penelitian ini menunjukkan hasil yang berbeda yaitu tidak terdapat hubungan yang bermakna antara derajat stunting dengan perkembangan motorik halus dan kasar anak balita. Tidak adanya hubungan tersebut mungkin disebabkan oleh terbatasnya keragaman data dikarenakan subyek dalam penelitian ini hanya terdiri dari anak balita dengan status gizi menurut $\mathrm{TB} / \mathrm{U}$ z-score < -1SD atau dengan kategori mild stunting, moderate stunting dan severe stunting. Keragaman data yang baik akan diperoleh apabila subyek juga terdiri dari anak balita dengan status gizi menurut $\mathrm{TB} / \mathrm{U}$-score $\geq-1 \mathrm{SD}$ atau dengan kategori normal, sehingga akan lebih jelas apakah terdapat hubungan antara derajat stunting dengan perkembangan motorik halus dan kasar anak balita. ${ }^{21}$ Alasan diatas didukung dengan penelitian cross-sectional di Cirebon pada pada anak stunting dan normal usia 1-5 tahun yang menunjukkan bahwa terdapat hubungan status stunting dengan perkembangan motorik balita. ${ }^{7}$ Tidak adanya hubungan antara derajat stunting dengan 
perkembangan motorik kasar dan halus juga dikarenakan perkembangan anak merupakan hal yang kompleks tidak hanya dipengaruhi oleh faktor stunting tetapi juga faktor lain seperti faktor biologi dan faktor lingkungan psikososial. ${ }^{18}$ Pada penelitian ini, pengaruh lingkungan biologi juga dianalisis yaitu dengan melihat besarnya asupan zat-zat gizi terutama yang berperan penting dalam perkembangan motorik. Meskipun anak dalam kondisi stunting, namun apabila ditunjang dengan asupan zat gizi yang baik maka perkembangan motoriknya juga dapat normal. Pengaruh faktor lingkungan psikososial, berdasarkan pengamatan diketahui bahwa lingkungan tempat tinggal balita merupakan lingkungan yang mendukung perkembangan motorik balita. Hal tersebut karena seringnya balita berinteraksi dengan teman sebayanya dan juga sebagian besar balita mengikuti program pendidikan usia dini, sehingga hal tersebut mungkin menyebabkan tidak ada hubungan antara derajat stunting dengan perkembangan motorik. Melalui bermain dan belajar secara tidak langsung merangsang atau menstimulus balita untuk berkembang sesuai dengan tahap perkembangan motoriknya. Stimulasi merupakan salah faktor psikologi yang merupakan kegiatan merangsang kemampuan dasar anak agar berkembang secara optimal. ${ }^{22}$ Studi yang dilakukan pada binatang menunjukkan bahwa stimulasi dapat meningkatkan percabangan dendrit dan jumlah serabut dendrit, sehingga akan meningkatkan pula koneksi dendrit. Koneksi dendrit bertanggung jawab pada timbulnya kemampuan motorik dan kognitif sehingga semakin banyak koneksi dendrit, kemampuan motorik dan kognitif juga akan semakin baik. ${ }^{23,24}$ Penelitian pada anak stunting di Jamaica menunjukkan bahwa perkembangan motorik anak lebih dipengaruhi oleh stimulasi daripada status gizi, dimana anak-anak yang stunting mengalami peningkatan skor perkembangan mental dan motorik yang hampir sama dengan anak-anak normal setelah menerima stimulasi dan suplementasi. $^{25}$

\section{Hubungan Asupan Zat Gizi dengan Perkembangan Motorik}

Asupan zat gizi merupakan kebutuhan dasar dalam proses tumbuh kembang anak, terutama tumbuh kembang otaknya di trimester ketiga kehamilan sampai usia tiga tahun. Asupan zat gizi yang penting untuk fungsi motorik meliputi energi, protein, besi, dan seng. ${ }^{4}$

Analisis pada penelitian ini menunjukkan terdapat hubungan yang bermakna secara statistika antara asupan energi dengan perkembangan motorik halus $(\mathrm{p}=0,040)$ dan motorik kasar $(\mathrm{p}=$ $0,020)$. Hal ini sesuai teori bahwa energi dalam fungsi motorik berperan dalam proses proliferasi dan diferensisasi sel dan synaptogenesis. ${ }^{4}$ Energi juga dapat mempengaruhi zat kimia yang ada di otak yaitu neurotransmitter. Neurotransmitter bertugas dalam menghantarkan impuls dari satu saraf ke saraf lainnya sehingga menghasilkan gerak motorik. $^{26}$ Energi juga dibutuhkan untuk mempertahankan hidup, menunjang pertumbuhan, dan melakukan aktivitas fisik. Aktivitas fisik adalah gerakan yang dilakukan oleh otot tubuh dan sistem penunjang. Selama aktifitas fisik, otot membututuhkan energi diluar metabolisme untuk bergerak, sedangkan jantung dan paru-paru memerlukan tambahan energi untuk mengantarkan zat-zat gizi dan oksigen ke seluruh tubuh dan untuk mengeluarkan sisa-sisa dari tubuh. Banyaknya energi yang dibutuhkan tergantung pada berapa banyak otot bergerak, berapa lama dan berat pekerjaan yang dilakukan. ${ }^{27}$ Energi tidak hanya digunakan oleh balita untuk pertumbuhan tetapi juga untuk perkembangan seperti bermain. Hasil penelitian di Bengkulu pada bayi usia 6-12 bulan menunjukkan hasil yang serupa bahwa asupan energi dari makanan pendamping ASI berhubungan dengan perkembangan motorik kasar. ${ }^{28}$ Penelitian lain pada bayi usia 6-11 bulan juga menyatakan bahwa asupan energi dari makanan pendamping ASI berhubungan dengan perkembangan bayi. ${ }^{10}$ Sebagian besar $(86 \%)$ asupan protein subjek penelitian dalam kategori baik. Hal ini karena hampir semua balita mengkonsumsi susu setiap hari dengan frekuensi 6-8 kali. Hasil analisis bivariat menunjukkan bahwa asupan protein mempunyai hubungan yang bermakna secara statistika dengan perkembangan motorik halus $(\mathrm{p}=0,045)$ dan motorik kasar ( $\mathrm{p}=0,027$ ). Adanya hubungan asupan protein dengan perkembangan motorik juga ditunjukkan pada penelitian dengan desain cross-sectional di Bengkulu yaitu pada bayi usia 6-12 bulan. ${ }^{28}$ Penelitian lain yaitu di Guatemala dengan desain penelitian kohort, diketahui bahwa asupan protein hewani dari makanan pendamping ASI berhubungan dengan kemampuan berjalan anak. ${ }^{29}$ Protein merupakan zat gizi yang berperan dalam fungsi motorik. Protein mempunyai fungsi yang sama dengan energi dalam fungsi motorik yaitu proses proliferasi, diferensisasi sel dan synaptogenesis. ${ }^{4}$ Protein disusun oleh asam amino yaitu esensial dan non esensial. Asam amino tirosin merupakan jenis asam amino yang 
berhubungan dengan mekanisme gerak motorik dimana tirosin merupakan penyusun dari neurotransmitter dopamine yang berperan dalam menghantarkan impuls dari satu saraf ke saraf lain. $^{26}$ Protein juga merupakan zat gizi yang berperan dalam membangun serta memelihara selsel dan jaringan. Kekurangan protein akan menyebabkan pertumbuhan terhambat, lemak dibawah kulit berkurang, otot-otot berkurang, dan melemah serta gangguan psikomotorik. ${ }^{27}$

Besi dan seng merupakan zat gizi esensial yang salah satunya berperan dalam fungsi motorik. Besi berperan dalam sintesis monoamine, metabolisme energi di neuron dan sel glia, mielinisasi, sistem neurotransmitter, dan metabolisme dopamine. Seng berperan dalam pelepasan DNA dan neurotransmitter. ${ }^{4}$ Hasil penelitian ini menunjukkan bahwa tidak terdapat hubungan asupan besi dan seng dengan perkembangan motorik halus maupun kasar. Tidak adanya hubungan tersebut mungkin karena terdapat bias saat pengukuran asupan besi dan seng subyek dengan menggunakan kuisioner food frequency semi quantitative. Bias dapat terjadi karena terdapat beberapa makanan terutama makanan jajanan yang tidak mencantumkan nilai gizi pada labelnya. Dari hal tersebut maka untuk menghitung kandungan zat besi dan seng dengan cara memperkirakan dari bahan-bahan yang mungkin sebagai penyusun produk makanan tersebut. Selain itu, bias juga dapat terjadi karena terkait dengan daya ingat responden tentang jumlah dan frekuensi makanan yang dikonsumsi balita. $^{30}$ Tidak adanya hubungan tersebut juga karena asupan besi dan seng yang diukur hanya asupan anak terutama saat tiga tahun pertama, sedangkan asupan gizi ibu saat hamil yaitu pada trimester ketiga kehamilan tidak diukur. Pada trimester ketiga kehamilan pertumbuhan dan perkembangan otak mulai terjadi sehingga dibutuhkan asupan gizi terutama besi dan seng yang tercukupi. ${ }^{4}$ Tidak diukurnya asupan besi dan seng saat ibu hamil dengan pertimbangan bahwa pola makan ibu saat hamil dan setelah melahirkan berbeda dan terkait dengan daya ingat ibu yang akan menyebabkan bias.

\section{Hubungan Sosial Ekonomi Keluarga dengan Perkembangan Motorik}

Pendidikan orang tua berpengaruh terhadap perkembangan anak terutama pendidikan ibu. Hasil penelitian ini menunjukkan walaupun sebagian besar ibu berpendidikan relatif tinggi namun berdasarkan analisis bivariat diketahui bahwa tidak terdapat hubungan pendidikan ibu dengan perkembangan motorik halus dan kasar. Tidak terdapat hubungan tersebut karena seorang ibu yang berpendidikan tinggi belum tentu memiliki pengetahuan yang baik mengenai gizi dan tumbuh kembang anak. Apabila seseorang tidak sering mencari atau mendapatkan informasi mengenai gizi dan tumbuh kembang anak, maka pengetahuan mengenai hal tersebut juga kurang sehingga mempengaruhi pola asuh terhadap anak. ${ }^{31}$ Pola asuh merupakan lingkungan psikologis yang dapat mempengaruhi perkembangan motorik anak. $^{18}$

Pada penelitian ini diketahui bahwa banyak ibu yang dikategorikan tidak bekerja atau sebagian besar adalah ibu rumah tangga. Ibu rumah tangga cenderung memiliki alokasi waktu yang cukup banyak untuk mengasuh anak. Dari tabel 5 dan 6 diketahui bahwa ibu yang tidak bekerja $86,2 \%$ mempunyai anak dengan perkembangan motorik kasar dan halus normal. Namun demikian, hasil analisis menunjukkan bahwa status pekerjaan ibu tidak berhubungan dengan perkembangan motorik. Tidak adanya hubungan tersebut dikarenakan tidak diketahui bagaimana pola pengasuhan ibu kepada anak terutama interaksi ibu dengan anak. Meskipun ibu memiliki alokasi waktu yang banyak untuk mengasuh anak, tetapi belum tentu ibu dapat mengoptimalkan interaksi dengan anak yang merupakan sarana pemberian stimulasi. Menurut Grantham Mc Gregor bahwa dalam proses perkembangan anak yang terpenting tidak hanya berapa waktu ibu bersama anaknya setiap hari, namun pada intensitas interaksi ibu dan anak sewaktu mereka sedang bersama-sama. ${ }^{11}$ Alasan lain status pekerjaan ibu tidak berhubungan dengan perkembangan motorik balita karena pada ibu yang bekerja banyak anak yang mempunyai perkembangan normal. Hal tersebut karena pengasuhan anak dilakukan oleh keluarga dekat ibu sehingga dimungkinkan pengasuhan masih baik dan dapat menunjang perkembangan motorik.

Berdasarkan analisis bivariat diketahui bahwa tidak ada hubungan pendapatan per kapita rumah tangga dengan perkembangan motorik kasar dan halus anak balita. Tidak adanya hubungan tersebut karena pendapatan per kapita merupakan faktor tidak langsung yang mempengaruhi perkembangan anak. Dengan pendapatan yang memadai orang tua dapat menyediakan kebutuhan anak baik primer maupun sekunder yang mendukung pertumbuhan dan perkembangan anak. $^{12,18}$ Dalam penelitian ini diketahui bahwa sebagian besar orang tua telah mampu mencukupi kebutuhan primer anak yaitu pemenuhan asupan 
pangan terutama asupan energi dan protein. Asupan energi dan protein dalam penelitian ini diketahui memiliki hubungan yang bermakna dengan perkembangan motorik halus dan kasar anak balita karena terkait dengan fungsi zat gizi tersebut dalam perkembangan motorik.

\section{KETERBATASAN PENELITIAN}

Penelitian ini memiliki keterbatasan dalam pelaksanaannya, yaitu tidak semua faktor yang mempengaruhi perkembangan motorik anak diteliti seperti faktor genetik, faktor pranatal yaitu gizi ibu pada waktu hamil, dan lingkungan psikososial seperti stimulasi. Selain itu, keterbatasan penelitian karena terdapat bias saat pengukuran asupan zat gizi dengan kuisioner food frequency semi quantitative.

\section{SIMPULAN}

Asupan energi dan protein berhubungan dengan perkembangan motorik halus dan kasar anak balita. Tidak ada hubungan antara derajat stunting, asupan besi, asupan seng, pendidikan ibu, pekerjaan ibu, dan pendapatan per kapita rumah tangga dengan perkembangan motorik halus dan motorik kasar anak balita.

\section{SARAN}

Perlu adanya penelitian lebih lanjut mengenai beberapa variabel yang mempengaruhi perkembangan balita seperti faktor genetik, faktor pranatal, faktor lingkungan psikososial, dan faktor lain yang mempengaruhi perkembangan motorik anak balita. Penelitian selanjutnya sebaiknya mengikutsertakan kelompok dengan status gizi TB/U normal sebagai pembanding dan dengan desain yang berbeda. Selain itu, perlu adanya pemberian informasi khususnya kepada ibu balita mengenai zat-zat gizi yang mempunyai peranan penting dalam pertumbuhan dan perkembangan anak.

\section{DAFTAR PUSTAKA}

1. Black RE, Morris SS, Bryce J. Where and Why are 10 Million Children Dying Every Year? Lancet. 2003;361 (9376):2226-34.

2. Badan Penelitian dan Pengembangan Kesehatan Departemen Kesehatan RI. Laporan Nasional Riset Kesehatan Dasar (Riskesdas) 2010. Jakarta; 2010.

3. Dinas Kesehatan Kota Semarang. Seksi Gizi DKK Semarang. Hasil Pemantauan Status Gizi Anak Bawah Lima Tahun 2011. Semarang: DKK Semarang; 2011.
4. Georgieff MK. Nutrition and Developing Brain: Nutrient Priorities and Measurement. Am J Clin Nutr. 2007; 85: 614S-20S.

5. Levitsky DA, Strupp BJ. Malnutrition and The Brain: Changing Concepts, Changing Concerns. J Nutr. 1995; 74: 381-6.

6. Udani PM. Brain and Various Facets of Child Development. Indian J Pediatrict. 1992,59: 165186.

7. Hizni A. Hubungan Satatus Stunted dengan perkembangan anak balita di Wilayah Pesisir Pantai Utara Kecamatan Lemah Wungkuk Kota Cirebon [tesis]. Yogyakarta: Program Pascasarjana Minat Utama Gizi dan Kesehatan Program Studi Ilmu Kesehatan Masyarakat Universitas Gajahmada; 2009.

8. Chang SM, Walker SP, Grantham SM, Powell CA. Early Childhood Stunting and Later Fine Motor Abilties. Journal Compilation Mac Keith Press.2010;52:831-836.

9. Gamayanti IL. Upaya Optimalisasi Fungsi Kognitif dan Psikomotrik Anak Stunting. Makalah disampaikan di: Seminar Nasional Optimalisasi Potensi Anak Stunting di Indonesia; 2 Oktober 2010; Yogyakarta.

10. Nurhayati. Hubungan Jumlah Asupan Makanan Pendamping ASI dengan Perkembangan Bayi Usia 6-11 bulan di Wilayah Kerja Puskesmas Lendah II Kabupaten Kulon Progo Yogyakarta [tesis]. Yogyakarta: Program Pascasarjana Program Studi Ilmu Kesehatan Masyarakat Universitas Gajahmada; 2011.

11. Grantham -McGregor SM, Yin BC, Cueto S, Glewwe P, Richter L, Strupp B et al. Developmental potential in the first 5 year for children in developing countries. Lancet 2007; 369(9555): 60-70.

12. Santos DN, Assis AMO, Bastos ACS, Strina A, Prado MS, Barreto ML et al. Determinant of Cognitive Function on Childhood: a cohort study in a middle income context. BMC. 2008;8:202.

13. Puskesmas Bugangan. Laporan Pemantauan Status Gizi 2011. Semarang: 2011.

14. World Health Organization (WHO). Measuring Change in Nutritionals Status Guildnes for Assessing the Nutritional Impact of Supplementary Feeding Programmes for Vulnerable Groups. Geneva; 1983.

15. Walker WA, Watkins JB, Duggan C. Nutrition in Pediatrics. Basic Science and Clinical Applications. 3nd edition. London : BC Decker Inc; 2003.p. 93.

16. Lembaga Negara Republik Indonesia. Peraturan Pemerintah Republik Indonesia No.47 Tahun 2008 Tentang Wajib Belajar. Jakarta:2008. 
17. BPS. Penduduk Miskin Kabupaten/Kota Jawa Tengah 2012 [Internet]. 2012 [cited 2012 juli 15]. Available From: http://www.Jateng.bps.go.id.

18. Soetjiningsih. Tumbuh Kembang Anak. Jakarta: EGC;1998.

19. Frankenburg WK, Dodds JB. Manual Tes Denver II. Edisi Kedua, alih bahasa oleh Subbagian Tumbuh Kembang Bagian Ilmu Kesehatan Anak FK UGM. Yogyakarta: FK UGM; 2009.

20. Gibson R. Principles of Nutritional Assesment. 2nd ed. Newyork: Oxford University Press Inc; 2005.p.256.

21. Dahlan MS. Statistik Untuk Kedokteran dan Kesehatan. Jakarta: Salemba Medika; 2011.hal.13.

22. Depkes RI. Pedoman Pelaksanaan Stimulasi, Deteksi dan Intervensi Dini Tumbuh Kembang Anak di Tingkat Pelayanan Kesehatan Dasar. Jakarta: Depkes RI; 2006.hal.15.

23. Restivo L, Ferrari F, Passino E, Sgobio C, Bock J, Oostra BA, et al. Enriched environment promotes behavioral and morphological recovery in a mouse model for the fragile $\mathrm{X}$ syndrome. PNAS, [Internet]. 2005. [citied 2012 August 01]; 102: 11557-62. Available from: http://www.pnas.org

24. Papalia DE, Old SW, Feldman RD. Human Development (Psikologi Perkembangan), alih bahasa oleh A. K. Anwar. Jakarta: Kencana; 2008.

25. Walker WA, Watkins JB, Duggan C. Nutrition in Pediatrics. London: BC Decker Inc; 2003.p.388393, 540-547.

26. Westermack T, Antila E. Diet in Relation to the Nervous System. In Garrow JS, James WP, Ralph A, editors. Human Nutrition and Dietetik. $10^{\text {th }}$ edition. New York: Churchill Living Stone; 2000.

27. Almatsier S. Prinsip Dasar Ilmu Gizi. Jakarta: Gramedia Pustaka Utama; 2002.

28. Herwan A. Hubungan Pola Makan Pendamping ASI dengan Pertumbuhan Gerak Motorik Kasar Bayi 6-12 Bulan di Kecamatan Bermani Ulu Kabupaten Rejang Lebong Propinsi Bengkulu [tesis]. Yogyakarta: Program Pascasarjana Program Studi Ilmu Kesehatan Masyarakat Universitas Gajahmada; 2005.

29. Kuklina EV, Ramakrishnan U, Stein AD, Barnhart $\mathrm{HH}$, Martorell R. Growth and Diet Quality are Associated with the Attainment of Walking in Rural Guatemalan Infants. J Nutr.2004;134: 32963300.

30. Supariasa IDN, Bakri B, Fajar I. Penilaian Status Gizi. Jakarta: EGC. 2001.hal.98-101

31. Soekidjo Notoatmodjo. Pendidikan dan Perilaku Kesehatan. Jakarta: Rineka Cipta. 2003.p 121-125. 